\title{
Design and performance of subirrigation system in maize (Zea mays) in Kumulur farm, Trichy district, Tamil Nadu, India
}

\section{A. Selvaperumal}

Department of Soil and Water Conservation Engineering, Tamil Nadu Agricultural University, Coimbatore (Tamil Nadu), India

G. Thiyagarajan*

Water Technology Centre, Tamil Nadu Agricultural University, Coimbatore (Tamil Nadu), India Thangamani. S

Department of Soil and Water Conservation Engineering, Tamil Nadu Agricultural University, Coimbatore (Tamil Nadu), India

\section{Vallalkannan, $\mathbf{S}$}

Department of Agriculture sciences and Engineering, Agricultural Engineering College and Research Institute, Trichy (Tamil Nadu), India

\section{K. Ramaswamy}

Department of Soil and Water Conservation Engineering, Tamil Nadu Agricultural University, Coimbatore (Tamil Nadu), India

${ }^{*}$ Corresponding author. Email: thiyagu@tnau.ac.in

\section{How to Cite}

Selvaperumal , A. et al. (2021). Design and performance of subirrigation system in maize (Zea mays) in Kumulur farm, Trichy district, Tamil Nadu, India. Journal of Applied and Natural Science, 13(2), 470 - 475. https://doi.org/10.31018/jans.v13i2.2623

\begin{abstract}
Subirrigation system can furnish water to plants. The upward flux and the discharge rate must satisfy the plant's lifesaving irrigation needs during summer. The experiment was laid out in A-block of Eastern farm, Agricultural Engineering College and Research Institute, Kumulur, Trichy, Tamil Nadu. Subirrigation system spacing was arrived using Moody's equation calculated as $10 \mathrm{~m}$. The experiment was laid out in spilt plot design with three replications. Four drain spacing levels $(7.5,10,12.5$ and 15 $\mathrm{m})$ were the main plot treatments and two levels of depth and diameter of drain pipes $(75 \mathrm{~cm}, 60 \mathrm{~cm} \& 75 \mathrm{~mm}, 63 \mathrm{~mm})$ were the sub plot treatments. The highest volumetric water content was recorded in $7.5 \mathrm{~m}$ spacing $+45 \mathrm{~cm}$ soil depth + lower reach $\left(\mathrm{S}_{1} \mathrm{~T}_{3} \mathrm{~T}_{1}\right)$. Capillary rise on water table management system under subirrigation mode was fixed as $33.5 \mathrm{~cm}$ and the average deep percolation loss was obtained in $0.3 \mathrm{~cm} / \mathrm{d}$ at development stage of crop period. The highest maize yield (4.30 t/ha) was obtained in $7.5 \mathrm{~m}$ spacing $+60 \mathrm{~cm}$ drain depth $+75 \mathrm{~mm}$ diameter $\left(\mathrm{S}_{1} \mathrm{D}_{3}\right)$. The highest water use efficiency of $\left(0.86 \mathrm{~kg} / \mathrm{m}^{3}\right)$ was recorded in $7.5 \mathrm{~m}$ spacing $+60 \mathrm{~cm}$ drain depth $+75 \mathrm{~mm}$ drain diameter $\left(\mathrm{S}_{1} \mathrm{D}_{3}\right)$. This subirrigation system could furnish water to plants due to upward flux and the same system also functioned efficiently under drainage modes and removed the waterlogging during wet periods.
\end{abstract}

Keywords: Capillary rise, Deep percolation, Subirrigation, Volumetric water content, Water Use efficiency

\section{INTRODUCTION}

Subirrigation is not often used in arid or semi-arid irrigated areas where irrigation is often needed to germinate crops. It is typically used in conjunction with subsurface drainage or controlled drainage. The subsurface drainage lowers the water table and removes excess water through open ditches or perforated pipe. The water table depth can be controlled by installing a weir on the drainage system. This water table is lowered in wet periods so that the root zone remains un- saturated. The water is pumped into the drainage system to raise the water table and provide additional water for plant growth in dry periods. In some conditions, drained water is stored for use when irrigating (Bjorneberg, 2013).

Gautham et al. (2019) showed that water could be supplied to root zone at a rate more than sufficient to satisfy plant needs for $7.5 \mathrm{~m}$ and15 $\mathrm{m}$ drain spacing's. However their response was too low for the $30 \mathrm{~m}$ tile lines and he concluded that both subirrigation and drainage requirements could be satisfied with $15 \mathrm{~m}$ 
drain spacing.

Subirrigation system effectiveness depends on several soil physical characteristics such as hydraulic conductivity and moisture holding capacity. The method can be used on soils having relatively low water holding capacities and high intake rates. Subirrigation systems do work satisfactorily in some areas, and it is stated that this system of irrigation, if properly designed and operated, might be the best method available for many areas. Hence the objective of the study was to design and performance of subirrigation system in maize (Zea mays) from May 2016 to August 2016 at farm Kumulur, Trichy, Tamil Nadu.

\section{MATERIALS AND METHODS}

The subirrigation experiment was conducted during May 2016 in A-block of Eastern farm, Agricultural Engineering College and Research Institute, Kumulur, Trichy, Tamil Nadu. Maize COHM6 (Z. mays)) was used as a test crop. Sandy loam soil is the soil type of the experimental area. The soil is sodic in reaction with a $\mathrm{pH}$ of 9.1 and electrical conductivity of $0.14 \mathrm{dS} \mathrm{m}^{-1}$. Maize COHM6 Hybrid medium duration variety of 118 days duration was used as a test variety for studying the subirrigation experiment. This system functions efficiently with both subirrigation and drainage modes and fulfilling both the needs. Subirrigation system can furnish water to plants, the upward flux and the discharge rate must satisfy the plant's life, saving irrigation is needed during summer. The same system operates the traditional drainage system during wet periods. Inevitably, if the system is efficient in subirrigation mode, it will satisfy the needs of the drainage also since the spacing requirement is less for subirrigation mode.

\section{Design consideration of subirrigation}

The hydraulic conductivity appears to decrease and become stable at a particular depth, indicating the depth of the impervious layer about 3.5 to $4.0 \mathrm{~m}$. The designing of the subirrigation system Moody (1966) equation was used.

Evapotranspiration rate (ER) recorded at Agricultural Engineering College and Research Institute, Kumulur, during summer, usually less than $5.0 \mathrm{~mm} / \mathrm{d}$ as per weather records, was considered design value for ' $e$ ' in Moody's equation. The water table depth to be maintained at the above drain points depends on the root zone depth and crop tolerance for wet conditions. For using this equation, the water table should be maintained to the depth of $0.4 \mathrm{~m}$ by considering the expected average root zone depth of $0.25 \mathrm{~m}$ and the midpoint water table should be held to the depth, not greater than $0.5 \mathrm{~m}$ from the surface.

Generally, in the study location, a water table depth of $0.45 \mathrm{~m}$ was observed. Hence the effective root zone depth was assumed as $0.3 \mathrm{~m}$ for sandy loam soil. The same Moody equation was used for finding out the drain spacing in subirrigation system as follows.

$$
\mathrm{L}^{2}=\frac{4 K\left(h_{0}^{2}-h_{1}^{2}\right)}{e}
$$

Where,

$\mathrm{L}=$ Spacing of drain $(\mathrm{m})$

$\mathrm{e}=$ Evapotranspiration rate, i.e. $5 \mathrm{~mm} / \mathrm{d}$

$\mathrm{K}=$ Hydraulic conductivity $(\mathrm{m} / \mathrm{d})$

$\mathrm{h}_{0}=$ Difference between depth to impervious layer to effective root zone of the crop (m)

$\mathrm{h}_{1}=$ Difference between depth to impervious layer to height of water table above the water level in the drain (m)

$\mathrm{h}_{0}=4.0-0.3$

$\mathrm{h}_{0}=3.7 \mathrm{~m}$

$\mathrm{h}_{1}=4.0-0.5$

$\mathrm{h}_{1}=3.5 \mathrm{~m}$

Substitute the value in Eq. 1

$$
L^{2}=\frac{4 x 0.35\left(3.7^{2}-3.5^{2}\right)}{0.005}
$$

$\mathrm{L}=20.7 \mathrm{~m}$

\section{Equivalent depth under subirrigation mode}

$$
\mathrm{d}_{\mathrm{e}}=\frac{D}{1+\frac{D}{L}\left(\frac{8}{\pi} \ln \frac{D}{r_{e}}-3.4\right)}
$$

Substituting this $L$ value by considering effective radius of drains $\left(r_{\mathrm{e}}\right)$ as $0.036 \mathrm{~m}$ in Eq. 2

$\mathrm{d}_{\mathrm{e}}=0.39 \mathrm{~m}$

$\mathrm{m}=\mathrm{h}_{0}-\mathrm{h}_{1}$

$\mathrm{m}=3.7-3.5$

$\mathrm{m}=0.2$

By taking suitable corrections for convergence, the final equation for spacing reduces to

$\quad \mathrm{L}^{2}=\frac{4 k m\left(2 h_{0}^{\prime}-\frac{h_{0}^{\prime}}{h_{0}} m\right)}{e}$
$h_{0}^{\prime}=\mathrm{d}_{\mathrm{e}}+\mathrm{h}$
$=0.39+0.5$
$h_{0}^{\prime}=0.89 \mathrm{~m}$
\[ 4 x 0.35 \times 0.2\left(2 \times 0.89-\frac{0.89}{3.7} x 0.2\right) \]
$L^{2}=\frac{0.005}{\text { Drain Spacing for subirrigation }(\mathrm{L})=10 \mathrm{~m}}$
Design diameter of drain pipes
Wessling's equation (1964) for uniform flow in smooth
pipes and corrugated pipes derived from manning's
equation was used to calculate the size of the lateral
drain pipes. Size of the lateral pipe required to carry the
design flow rate is given as
$\mathrm{Q}=89$ (d $)^{2.716} \times(\mathrm{i})^{-0.572} \ldots \ldots \ldots \ldots \ldots(4)$
Where




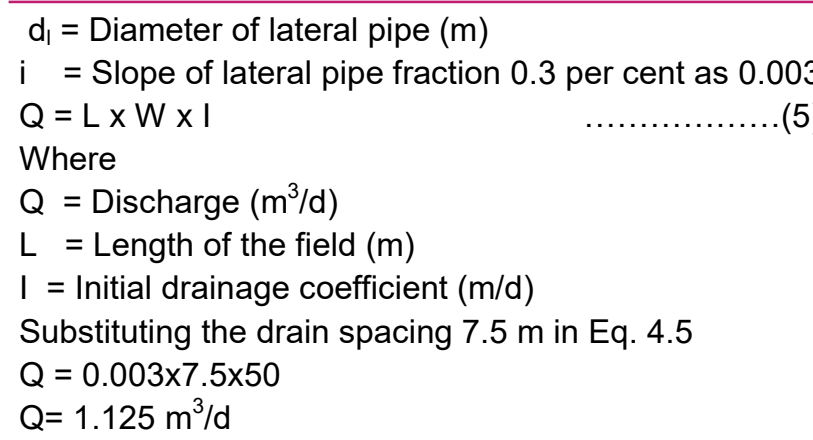

$$
1.125=89\left(d_{l}\right)^{2.716} x(0.003)^{-0.572}
$$

$\mathrm{d}_{1}=58 \mathrm{~mm}$

The commercial available pipe diameter of $63 \mathrm{~mm}$ and $75 \mathrm{~mm}$ was used for all the spacing.

The experiment was laid out in split plot design with three replications. For field practical sensitivity analysis $7.5,10,12.5$ and $15 \mathrm{~m}$ spacing are main plot treatments and two levels of depth and diameter of drain

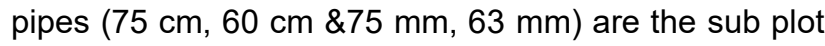
treatments. Less water requirement crop (maize) was cultivated during summer as a test crop for finding out the suitability of subirrigation system.

Performance and evaluation of subirrigation system

The initial moisture at different depths in the near, middle and farther end midway between the laterals were observed. After the pumping operation, the soil moisture content depletion was recorded at a frequent interval of 24 hours for the period of 4 days from the date of irrigation at midway between the laterals at lower $\left(T_{1}\right)$ middle $\left(T_{2}\right)$ and farther ends $\left(T_{3}\right)$ at three different depths of $15 \mathrm{~cm}\left(t_{1}\right), 30 \mathrm{~cm}\left(t_{2}\right)$ and $45 \mathrm{~cm}\left(t_{3}\right)$. Similarly, the subirrigation treatments during summer were taken for performance evaluation by reversibly pumping water in to the system.

\section{Design considerations of capillary zone thickness}

During subirrigation water is transmitted from the water table through the capillary zone to the plant's root system. Peck et al. (1974) proposed an empirical relationship to relate the height of capillary rise to an inverse function of the product of void ratio (e) and grain size distribution of soil particle as

$\mathrm{H}_{\mathrm{c}}=\mathrm{C} /(\mathrm{e} \times \mathrm{d})$

where

$\mathrm{H}_{\mathrm{c}}=$ Height of the capillary rise $(\mathrm{mm})$

$\mathrm{d}=$ Grain size distribution of soil particle $(\mathrm{mm})$

e $=$ Void ratio

$C=$ Constant depending varying between 10 to $50 \mathrm{~mm}^{2}$ on surface impurities and grain shape

\section{Deep percolation loss in subirrigation system}

Deep percolation is estimated using the water balance equation (Upreti et al.2015). The water balance equa- tion for the field can be expressed as

$\Delta \mathrm{S}=\mathrm{P}+\mathrm{I}-\mathrm{ET}-\mathrm{DP}-\mathrm{HS}-\mathrm{R}$

Where

$\Delta S=$ Change is storage in the root zone

$\mathrm{P}=$ Precipitation $(\mathrm{mm})$

I = Irrigation water $(\mathrm{mm})$

$\mathrm{ET}=$ Actual Evapotranspiration $(\mathrm{mm})$

$\mathrm{DP}=$ Deep percolation $(\mathrm{mm})$

$\mathrm{R}=$ Surface Runoff $(\mathrm{mm})$

As the experiment in the study area, the horizontal seepage is zero and surface runoff is negligible. So that water balance equation becomes,

$\Delta \mathrm{S}=\mathrm{P}+\mathrm{I}-\mathrm{ET}-\mathrm{DP}$

Rearranging equation (7) and knowing all the variable, deep percolation is estimated using,

$\mathrm{DP}=\mathrm{P}+\mathrm{I}-\mathrm{ET}-\Delta \mathrm{S}$

Change in storage $(\Delta S)$ using the initial and final moisture content reading over required time duration.

\section{Determination of water use efficiency}

Water Use Efficiency (WUE) was calculated for each treatment, which is the ratio of yield of the crop in $\mathrm{kg} / \mathrm{ha}$ and total water applied in $\mathrm{mm}$.

WUE $=\frac{Y}{W}$

WUE - Water Use Efficiency, $\left(\mathrm{kg} / \mathrm{m}^{3}\right)$

Y $\quad$ - Yield of the crops, $(\mathrm{kg} / \mathrm{ha})$

W - Total water applied, (mm)

\section{RESULTS AND DISCUSSION}

\section{Soil moisture distribution pattern under} subirrigation system:

\section{Horizontal direction of soil moisture distribution at $60 \mathrm{~cm}$ depth}

The highest volumetric water content (32 per cent) was recorded in $7.5 \mathrm{~m}$ spacing $+45 \mathrm{~cm}$ soil depth + lower reach $\left(S_{1} t_{3} T_{1}\right)$, whereas the lowest value (14.2 per cent) in $15 \mathrm{~m}$ spacing $+15 \mathrm{~cm}$ soil depth + farther reach $\left(S_{4} t_{1} T_{3}\right)$ on $1^{\text {st }}$ day of observation in horizontal direction of drain pipes at $60 \mathrm{~cm}$ drain depth. Similar trend was obtained in all other days of observation viz., one day after irrigation, two day after irrigation and third day after irrigation.

\section{Horizontal direction of soil moisture distribution at $75 \mathrm{~cm}$ depth}

The highest volumetric water content (29.9 per cent) was recorded in $7.5 \mathrm{~m}$ spacing $+45 \mathrm{~cm}$ soil depth + lower reach $\left(\mathrm{S}_{1} \mathrm{t}_{3} \mathrm{~T}_{1}\right)$. In contrast, the lowest value (11.9 per cent) in $15 \mathrm{~m}$ spacing $+15 \mathrm{~cm}$ soil depth + farther reach $\left(\mathrm{S}_{4} \mathrm{t}_{1} \mathrm{~T}_{3}\right)$ on $1^{\text {st }}$ day of observation in horizontal direction of drain pipes at $75 \mathrm{~cm}$ drain depth. 
Similar trend was obtained in all three days of observation viz., one day after irrigation, two days after irrigation and third day after irrigation.

There was a gradual decline in the volumetric water content toward farther ends within the effective area midway between drains. Increase in volumetric water content at both horizontal and vertical direction of drain spacing within the profile. i.e. through 15,30 , and 45 $\mathrm{cm}$ soil depth. More volumetric water content reading was noticed in $60 \mathrm{~cm}$ drain depth than $75 \mathrm{~cm}$ drain depth. This might be due to the less opportunity time and limited capillary rise for the water to rise from drain level. It was observed that near the collector, i.e. lower reaches, higher soil volumetric water content was found because the pressure build up near the valves made the water rise up and oozing to the surface, causing surface inundation. The variation of average soil moisture distribution at different spacing and depth is presented in Fig. 1 to 2 . Similar results found by Prabhakar et al. (1991) reported that the moisture content gradually decreased while the increased distance from the emitter. Skaggs et al. (1972) showed that $7.5 \mathrm{~m}$ and 15 $\mathrm{m}$ spacing were adequate to fulfill the crop water use, while the $30 \mathrm{~m}$ spacing was inadequate to maintain the targeted water table level. Chakraborty et al. (2008) also reported that the soil water content was relatively higher by volume near the emitter and it was decreasing as the distance from the emitting point increased. Gowtham et al. (2019) concluded that $80 \mathrm{~cm}$ drain depth had lower gravimetric moisture content than the drain depth of $60 \mathrm{~cm}$ and reported that the soil water content was relatively higher by volume near the emitter and it was decreasing as the distance from the emitting point increased.

\section{Capillary rise and deep percolation losses on subirrigation system}

The capillary rise was calculated by using the formula $\left(\mathrm{H}_{\mathrm{c}}=\mathrm{C} / \mathrm{e} \times \mathrm{d}\right)$, considering the average size of the sandy loam soil particles (d) is $0.50 \mathrm{~mm}$, considering the same value for surface impurities and grain shape (C) and void ratio (e) (0.48). Hence the capillary rise on water table management system under subirrigation mode is fixed as $33.5 \mathrm{~cm}$. similar result found by Liu et al. (2014) concluded that natural sand actually gave a capillary rise of $62.5 \mathrm{~cm}$. The average deep percolation losses were obtained at development stage, mid stage and maturity stage are $0.3,0.2 \& 0.15 \mathrm{~cm} \mathrm{~d}^{-1}$. Similar results found by Upretiet al. (2015) reported that deep percolation was calculated using the water balance approach and also concluded that at initial stage, development stage, mid stage and late stage of deep percolation, losses were observed in 10, 22, 18 and $12 \mathrm{~mm} / \mathrm{d}$.

\section{Maize yield under subirrigation system}

The maize was raised in $75 \mathrm{~cm}$ and $60 \mathrm{~cm}$ drain depth for all the spacing to test the water table management system's performance under subirrigation mode. The
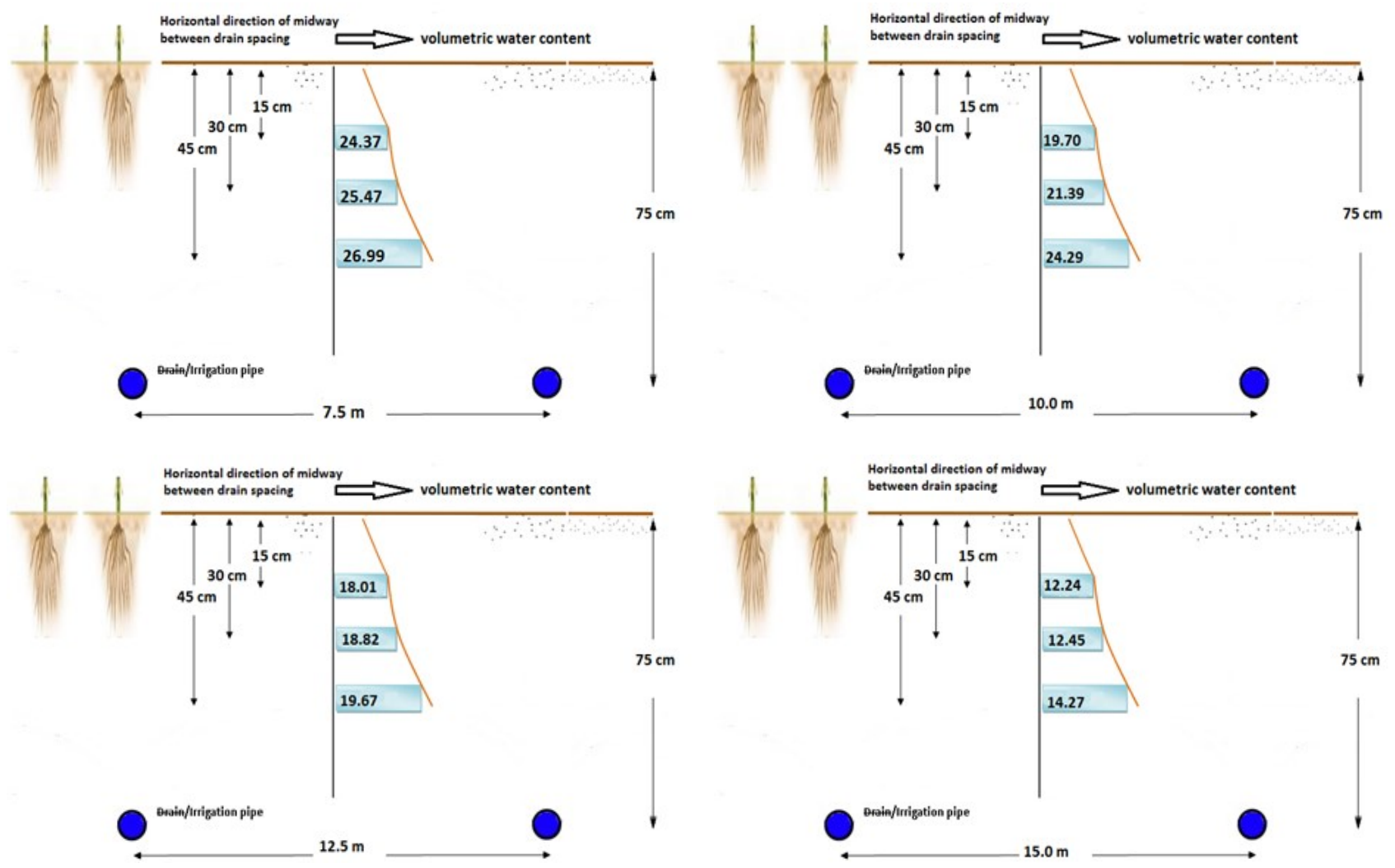

Fig. 1. Horizontal direction of soil moisture distribution pattern at $75 \mathrm{~cm}$ depth under different spacing. 

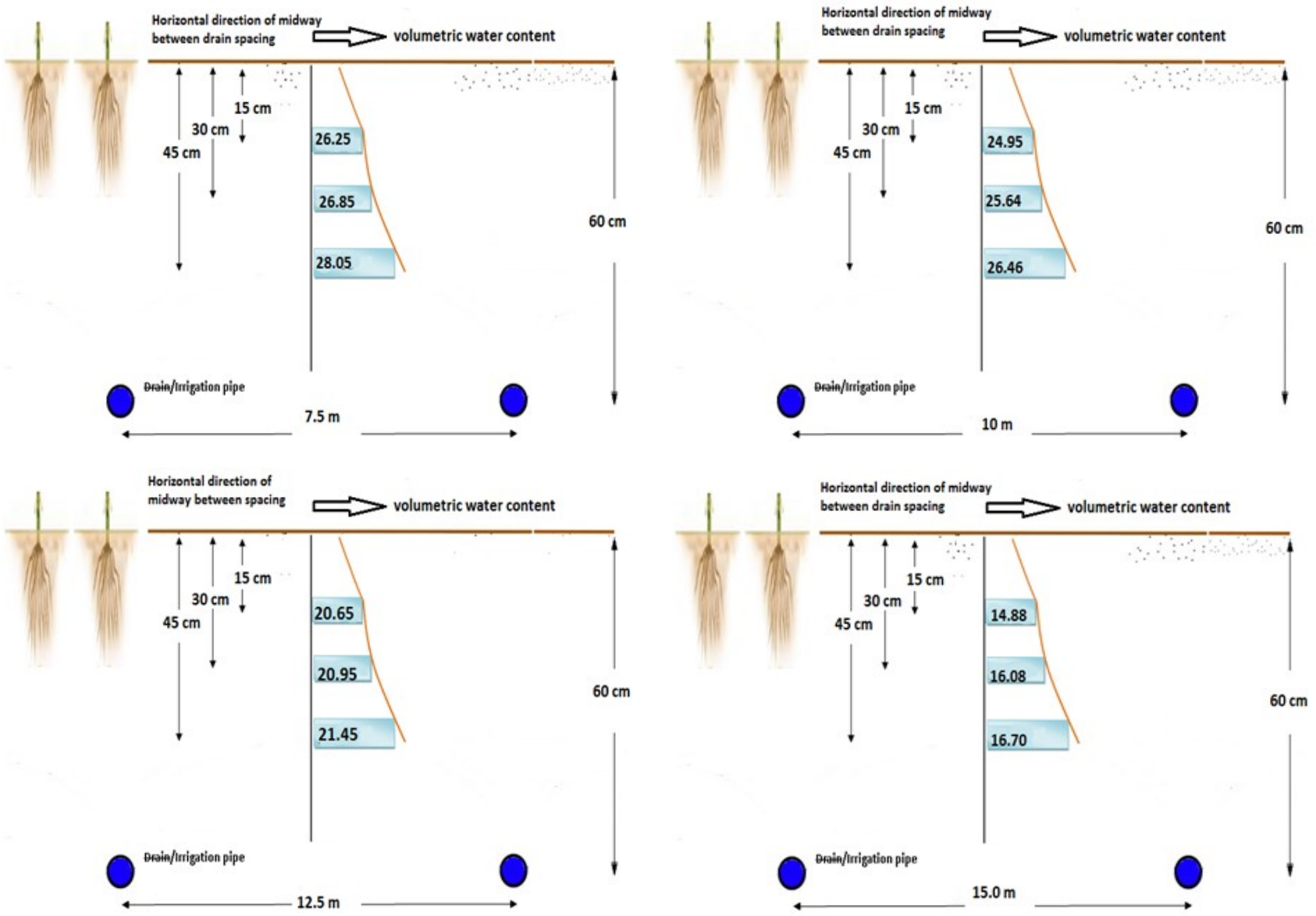

Fig. 2. Horizontal direction of soil moisture distribution pattern at $60 \mathrm{~cm}$ depth under different spacing.

highest maize yield (4.30 t/ha) was obtained in $7.5 \mathrm{~m}$ spacing $+60 \mathrm{~cm}$ drain depth $+75 \mathrm{~mm}$ diameter $\left(\mathrm{S}_{1} \mathrm{D}_{3}\right)$ whereas the lowest value (3.40 t/ha) in $15 \mathrm{~m}$ drain spacing $+75 \mathrm{~cm}$ drain depth $+75 \mathrm{~mm}$ drain diameter $\left(S_{4} D_{1}\right)$. The yield data of maize recorded at $60 \mathrm{~cm}$ and $75 \mathrm{~cm}$ drain depth is presented in Fig. 3. Fisher et al. (1999) reported that Maize crop had higher yield with subirrigation with more effectiveness in subirrigation . Ghaffer and Wahba (2006) revealed that wheat crop yield was higher by 15 per cent with subirrigation treatment compared to surface irrigation treatment. Gubir

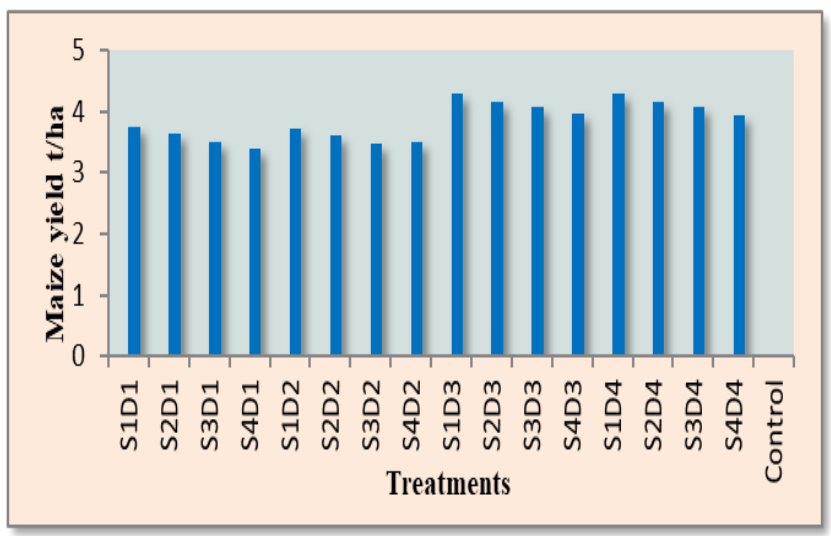

Fig. 3. Maize yield after various treatments.
Singh et al. (2021) reported that grain yield variability generally decreased from a dry to a normal year. Longterm yield data indicated that narrower drain tile spacings with subirrigation reduce grain yield variability in dry and wet environments; however, the costeffectiveness of these systems needs to be determined.

\section{Water Use efficiency under subirrigation system}

The highest water use efficiency of $\left(0.86 \mathrm{~kg} / \mathrm{m}^{3}\right)$ was recorded in $7.5 \mathrm{~m}$ spacing $+60 \mathrm{~cm}$ drain depth +75

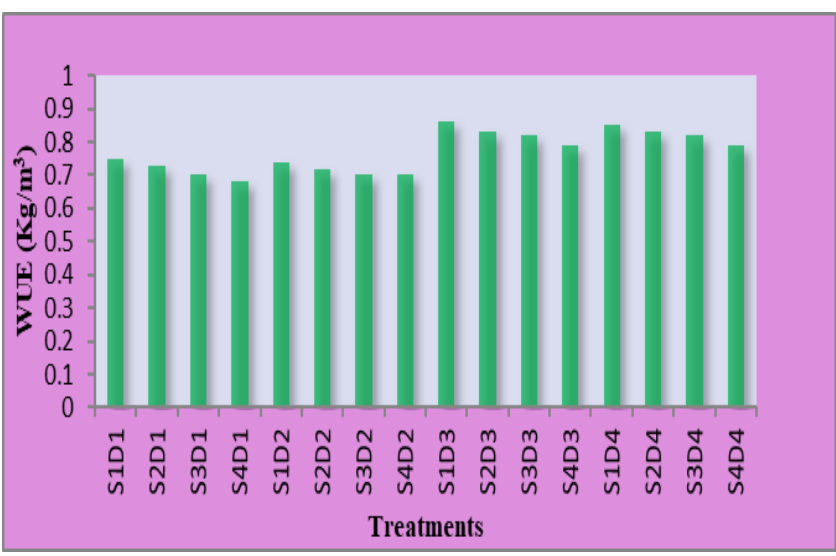

Fig. 4. Water-use efficiency in various treatments. 
$\mathrm{mm}$ drain diameter $\left(\mathrm{S}_{1} \mathrm{D}_{3}\right)$ whereas the lowest value $\left(0.68 \mathrm{~kg} / \mathrm{m}^{3}\right)$ in $15 \mathrm{~m}$ spacing $+75 \mathrm{~cm}$ drain depth +63 $\mathrm{mm}$ drain diameter. $\left(\mathrm{S}_{4} \mathrm{D}_{1}\right)$. The water use efficiency for all the treatments are presented in Fig. 4. Similarly, Martinez (2014) has reported that the subirrigation method seemed to perform better than the conventional irrigation system because the yield and the irrigation water use efficiency were higher.

\section{Conclusion}

The present study concluded that Subirrrigation system operated the traditional drainage system during wet periods. Subirrigation system spacing was arrived using Moody's equation calculated as $10 \mathrm{~m}$. The highest volumetric water content was recorded in $7.5 \mathrm{~m}$ spacing $+45 \mathrm{~cm}$ soil depth + lower reach $\left(\mathrm{S}_{1} \mathrm{t}_{3} \mathrm{~T}_{1}\right)$. Capillary rise on water table management system under subirrigation mode was fixed as $33.5 \mathrm{~cm}$ and the average deep percolation loss was obtained in $0.3 \mathrm{~cm} / \mathrm{d}$ at the development stage of crop period. The highest maize yield ( $4.30 \mathrm{t} / \mathrm{ha}$ ) was obtained in $7.5 \mathrm{~m}$ spacing $+60 \mathrm{~cm}$ drain depth $+75 \mathrm{~mm}$ diameter $\left(\mathrm{S}_{1} \mathrm{D}_{3}\right)$. The highest water use efficiency of $\left(0.86 \mathrm{~kg} / \mathrm{m}^{3}\right)$ was recorded in $7.5 \mathrm{~m}$ spacing $+60 \mathrm{~cm}$ drain depth $+75 \mathrm{~mm}$ drain diameter $\left(S_{1} D_{3}\right)$. The present subirrigation system could furnish water to plants due to upward flux, and the same system also functioned efficiently under drainage modes to remove the waterlogging during wet periods and hence will benefit the farmers.

\section{ACKNOWLEDGEMENTS}

I am grateful to Agricultural Engineering College and Research Institute (AEC\&RI) Kumulur and Tamil Nadu Agricultural University Coimbatore for the approval of my research work.

\section{Conflict of interest}

The authors declare that they have no conflict of interest.

\section{REFERENCES}

1. Bjorneberg D.L. (2013) IRRIGATION | Methods, Reference Module in Earth Systems and Environmental Scienc- es, Elsevier, 2013. 11-Sep-13 doi: 10.1016/B978-0-12409548-9.05195-2, 273-280

2. Chakraborty, D.,Nagarajan, S., Aggarwal, P., Gupta, V.K., Tomar, R.K., Garg, R.N., Sahoo, R.N., Sarkar, A., Chopra, U.K., Sarma K.S. \& Kalra, N. (2008). Effect of mulching on soil and plant water status, and the growth and yield of wheat (Triticumaestivum L.) in a semi-arid environment. Agricultural water management, 95 (12), 1323-1334.

3. Ghaffer, A.E \& Wahba, M.A.S. (2006). Possibility of watertable management through sub-irrigation in egypt. Tenth int. water tech. conf., iwtc 10, alexandria, Egypt.

4. Gubir singh., Kelly., and Nelson. (2021). Long term drainage subirrigation and tile spacing effect on maize production. Field Crop Research, 262(1), 108012

5. Goutham deekshithulu, N.V., Hemakumar H.V., Mani A., Sujani Rao. \& Srinivasa RAO. (2019). Design of controlled drainage cum subirrigation system in waterlogged rice field of Bapatla. International Journal of Agriculture Sciences, 11(14), 8770-8775.

6. Fisher, M.J., Fausey, N.R., Subler, S.E., Brown, L.C. and Bierman, P.M. (1999). Water table management, nitrogen dynamics, and yields of corn and soybean. Soil Science Society of America Journal, 63(6):1786-1795.

7. Liu, Q., Yasufuku, N., Miao, J. \& Ren. J. (2014). An approach for quick estimation of maximum height of capillary rise. Soils and Foundation, 54(6),1241-1245

8. Moody, W.T. (1966). Nonlinear differential equation of drain spacing. J. of Irri.and Drain. Divi., 92(2), 1-10.

9. Peck, R.B., Hanson, W.E. and Thornburn, T.H. (1974). Foundation Engineering. Wiley, New York.

10. Prabhakar, M., Srinivas, K. \& Hegde, D.M. (1991). Effect of Irrigation Regimes and Nitrogen Fertilization on Growth, Yield, N Uptake, and Water Use of Carrot .Food and Agriculture organization of united nations. AGRIS., 56 (5), 206-209.

11. Skaggs, R.W., Kriz, G.D. \& Bernal, R. (1972). Irrigation through subsurface drain. J. of Irri. and Drain. Divi., ASAE, 98(3), 363-373.

12. Wessling, J. (1964). Subsurface flow in to drain. Drainage principle and applications Journal of Hydrology, 2(1), 2532

13. Uan Martinez \& Juan reca (2014). Water Use efficiency of drip irrigation versus an alternative sub surface drip irrigation methods. Journal of Irrigation and Drainage Engineering, 140(10), 1943 - 1956

14. Upreti, H., Ojha, C.S.P. \& Prasad, K.S.H. (2015). Estimation of deep percolation in sandy loam soil using water balance approach. Irrigat. Drainage Sys. Eng., S1(002), 1-4. 